MARKETS, MINDS, AND MONEY 



\title{
Markets, Minds, and Money
}

WHY AMERICA LEADS THE WORLD

IN UNIVERSITY RESEARCH

\section{MIGUEL URQUIOLA}

\author{
II Harvard University Press \\ 11 Cambridge, Massachusetts $\cdot$ London, England $\cdot 2020$
}


Copyright (C) 2020 by the President and Fellows of Harvard College All rights reserved

Printed in the United States of America

\section{First printing}

Cover photo: Getty Images @ David Sucsy

9780674246607 (EPUB)

97806742466r4 (MOBI)

978067424662 I (PDF)

The Library of Congress has cataloged the printed edition as follows:

Names: Urquiola S., Miguel (Urquiola Soux), author.

Title: Markets, minds, and money : why America leads the world in university research / Miguel Urquiola.

Identifiers: LCCN 2019046786 | ISBN 9780674244238 (cloth)

Subjects: LCSH: Education, Higher-Research-United States-History. I

Education, Higher-Economic aspects-United States-History. I

Universities and colleges-Graduate work-History. I Free

enterprise-United States-History. I Education, Higher-Aims and objectives-History.

Classification: LCC LB2326.3.U U4 2020 I DDC 378.007-dc23

LC record available at https://lccn.loc.gov/2019046786 